\title{
需要者の水道水に対するリスク認知における 構成概念の構造に関する分析
}

\author{
平山修久 ${ }^{1} \cdot$ 伊藤禎彦 $^{2} \cdot$ 加川孝介 $^{3}$ \\ ${ }^{1}$ 学生会員 修 (工) 京都大学大学院工学研究科環境工学専攻 ( $\bar{T}$ 606-8501 京都市左京区吉田本町) \\ ${ }^{2}$ 正会員 博 (工) 京都大学教授 大学院工学研究科都市社会工学専攻 ( $\%$ 606-8501 京都市左京区吉田本町) \\ ${ }^{3}$ 京都大学大学院工学研究科都市社会工学専攻 ( 7 606-8501 京都市左京区吉田本町)
}

\begin{abstract}
今後の上水道事業において, リスクを伝えるコミュニケーションの過程が重要となってきており, 新たな情 報公開技術が必要とされている. そこでは, 需要者がどのようにリスクを捉えるかを把握することが重要であり, そのリスク認知構造を明らかにすることが必要である。 まず, Semantic Differential 法によるアンケート調査をも とに, 水道水に対するリスク認知の構成要素を明らかにした。 確認的因子分析法を用いて, 需要者の水道水に 対するリスク認知における構成概念の構造モデルを構築し, 水道水質に対する安心感がどのように規定されて いるかについて考察し，情報量，未知性，安心感に因果連鎖があることを示した．また，水道水質については， よく知れば安心できるというものではない，ことを指摘した。
\end{abstract}

Key Words: risk perception, drinking water supply, confirmatory factor analysis, semantic differential method, construct

\section{1. 緒言}

今後の上水道事業において, リスクを伝えるコミュニ ケーションの過程が重要な課題となってきており, 新た なコミュニケーション手法あるいは情報公開技術が必要 とされている. そして, リスク・コミュニケーションあ るいは情報公開技術における最大の目標として, 需要者 である市民のリスク回避とともに不安感を低減あるいは 解消することがあげられる，需要者は一般に，リスクを 回避したり低減したりする方向で行動するが，このよう な需要者に対して, どのようにすれば, 適切にコミュニ ケーションすることができるのかが問題となる. そのた めには, 需要者がどのようにリスクを捉えるかを把握す ることが非常に重要であり, その認知レベルにおける心 理学的過程あるいはリスク認知構造を明らかにしていく ことが重要である.

これまでにも, リスク認知研究の分野において, 計量 心理学的手法を用いて人々のリスクに対する認知構造が 検討されている ${ }^{12.213) .4)}$. また, 伊藤, 平山 ${ }^{5)}$ は, 需要者 の水道水に対するリスク認知次元の検討を行い, 水道水 に対するリスク認知の構成要素を明らかにしている。
しかしながら，このような計量心理学的手法である 探索的因子分析では，人々のリスク事象に対する評価構 造を示すことができるが，必ずしも構成概念間の因果関 係を考慮したような分析モデルを確証することができ ない. Guttmanの は, 変数をいくつかのグループに分類し て，それぞれのグループに含まれる変数ごとに，因子分 析を適用する多群因子分析法を提唱している.さらに,

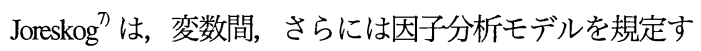
る各種の母数に関する事前の知識を積極的に取り込み, 因子分析に仮説検証機能を導人した確認的因子分析法を 提案している.

本研究は, 確認的因子分析法を用いて, 需要者の水道 水に対するリスク認知における潜在的因子間の因果関係 を考慮した構造モデルを構築することを目的とする. そ してその結果から, 水道水のリスク認知において, 安心 感がどのように規定されているのかを明らかにすること を目的とする。

本研究では, 需要者の水道水に対するリスク認知を数 量的に測定するために, Semantic Differential 法 (以下, SD 法とよぶ）によるアンケート調査を実施している。 そし て, 安心感, 未知性, ならびに情報量を潜在的構成概念 
として因子分析モデルに組み込み，構成概念間構造をモ デリングすることを試みる，そのうえで，情報量と安心 感との関連について考察を行った。

\section{2. アンケート調査概要}

\section{(1) 調査対象}

平成 14 年 7 月の時点において, 大阪府内で高度浄水 処理による水道水が供給されている市区町村の住民を対 象として，この対象地域内の電話帳データベース ${ }^{8)}$ から 3000 世帯を抽出した。ここでは，抽出した標本の地域 的偏りを減少させるため, 郵便番号デー夕, 住所デー夕 の特性による層化二段無作為抽出法を用いた。

\section{(2) 調査方法}

調査は, 平成 14 年 8 月 9 日〜 8 月 31 日の 3 週間に, 郵送調査法による質問紙調査で行われた。

\section{(3) 調査項目}

本アンケートで使用した調査票の構成を表-1 に示す. $\mathrm{SD}$ 法は，評定対象となる概念に対して個人が抱くイ メージや心理的意味を数量的に測定するための手法であ る9．本研究では，形容詞対の尺度による7段階で評定 させる SD 法を用いることとし，上水道システムに対す る認識ならびに水道水質に対する認識について, 図一-1 に示す 10 の尺度を用いて, 琵琶湖, 高度浄水処理, 卜 リハロメタンなどの概念を評定するよう求めた。

本研究はあくまでも水道水のリスク認知に着目する ものであって, 評定対象の一般的なイメージを把握する ことが目的ではない．むしろ水道水に関する概念に対す るリスク認知構造を捉えることが目的である.これら の理由から，ここで用いる尺度は， Slovic ${ }^{1)}$ がリスク・イ メージの構成要素を検討する際に因子分析で用いられた 18 の尺度を基に, 井上, 小林 ${ }^{10}$ が行った SD 法で用い て行われた233件の論文の形容詞対の検討結果を参考に, アンケート調査の分量を考慮して 10 の尺度を決定した。 なお，大学生を対象とした予備調査を行い，従来からの リスク認知研究で得られている「恐ろしさ」因子と「未 知性」因子が抽出されることを確認した。

\section{a) 上水道システムに対する認識}

上水道システムは，水道水源から適当な水質の水を取 り入れる取水施設，水道原水を浄水場まで輸送する導水 施設，原水を飲料水に適するよう処理する浄水施設，需 要者に供給する配水管などの配水施設, 配水管から給水 栓まで導水する給水施設，から構成されている ${ }^{11}$. Owen $ら^{12)}$ は, 需要者の水道水質の認識の分類モデルにおいて, 需要者か淂る一般知識を取水, 浄水, 配水, 給水に分類
表-1 アンケート調査票の構成

\begin{tabular}{|l|}
\hline A. 上水道システムに対する認識に関する質問 \\
以下の $(1) \sim(5)$ にいて, 図-1 に示す尺度の評定 \\
を依頼 \\
(1) 琵琶湖 \\
(2) 淀川 \\
(3) 浄水場 \\
(4) 高度浄水処理 \\
(5) 水道管 \\
B. 水道水質に対する認識についての質問 \\
以下の (1)〜 (3)について, 図-1 に示す尺度の評定 \\
を依頼 \\
(1) 水道原水の水質 \\
(2) 塩素処理 \\
(3)トリハロメタン \\
C. 個人属性に関する質問 \\
(1) 年齢 $\quad$ (2) 性別
\end{tabular}

\begin{tabular}{|c|c|c|}
\hline 親しみにくい & \begin{tabular}{|llllll} 
& $\perp$ & 1 & 1 & $\perp$ & $\perp$
\end{tabular} & 親しみやすい \\
\hline 技術的に制御可能 & \begin{tabular}{|llllll}
1 & 1 & 1 & 1 & $\perp$ & $\perp$
\end{tabular} & 技術的に制御不可能 \\
\hline 清潔な & \begin{tabular}{|lllll}
1 & 1 & 1 & 1 & 1
\end{tabular} & 不潔な \\
\hline リスク増大傾向 & $\begin{array}{llllll}1 & 1 & 1 & 1 & 1\end{array}$ & リスク減少傾向 \\
\hline 観察可能 & \begin{tabular}{lll|lll} 
& 1 & 1 & 1 & 1 & 1
\end{tabular} & 観察不可能 \\
\hline 一般に知られている & \begin{tabular}{|ll|lll}
1 & 1 & 1 & 1 & 1
\end{tabular} & 一般に知られていない \\
\hline 恐ろしい & \begin{tabular}{|lll|ll}
1 & 1 & & 1 & 1
\end{tabular} & 恐ろしくない \\
\hline 科学的に不明 & \begin{tabular}{|lllll}
1 & $\perp$ & $\perp$ & $\perp$
\end{tabular} & 科学的に解明 \\
\hline 複雑な & \begin{tabular}{|llllll}
1 & 1 & 1 & 1 & 1
\end{tabular} & 単純な \\
\hline リスクの軽減が困難 & \begin{tabular}{|lll|lll}
1 & $\perp$ & $\mid$ & $\perp$ & $\perp$
\end{tabular} & リスクの軽減が容易 \\
\hline
\end{tabular}

図-1 形容詞対の尺度による SD 法

している.

本研究では, 上水道システムを, 水道水源, 浄水施設, 配水・給水施設，と分類し，これらに関する事象を評定 対象となる概念として選ぶものとした．水道水源に属す る概念として, 大阪府の水道水源である「琵琶湖」「淀川」 をとりあげるものとした．浄水施設に関しては「浄水場」 「高度浄水処理」について評定してもらうよう依頼した。 配水・給水施設については，「水道管」をとりあげるも のとした。

b) 水道水質に対する認識

水道水質に対する認識についての質問では，まず「水 道原水の水質」について評定してもらった。

わが国では，水道の消毒には塩素を用いることになっ ている，また，水系伝染病を防止する観点から，給水 栓の末端においても消毒剤は残留していなければならな $い^{11}$. このことから, 「塩素処理」を水道水質に属する概 念としてとりあげるものとした.

また, 本研究では, 水道水に対するリスク認知に着目 することから, 水道水に関するリスクである有害化学物 質として,「トリハロメタン」をとりあげるものとした。 c) 個人属性に関する質問

個人属性については，年齢，性別を尋ねた。 また，回 
答は家族の誰が行ってもよいこととした。

\section{(4) アンケート調査結果}

郵送したアンケート調査票のうち，818 人から回答を 得た。回収率は $28.5 \%$ である。 また，その中で無効な回 答を除いた有効回答数は $668,23.3 \%$ であった. 有効回 答のうち男性の割合が $77.7 \%$ であった。 また，回答者の 平均年齢は 56.2 歳, 標準偏差は 13.3 で, 60 歳以上の割 合が $43.9 \%$ であった. 図-2 に回答者の年齢分布を示す.

概念別の尺度得点平均とその分散を表 -2 に示す。な お，「琵琶湖」という概念に対する「単純な」の尺度に ついての観測変数を「琵琶湖 - 単純な」のように, 以後, 「概念 - 尺度名」と表記するものとした。

\section{3. 分析方法}

(1) 探索的因子分析と確認的因子分析 ${ }^{13), 14)}$

探索的因子分析法は，一組の観測変数の背後に少数の 構成概念を仮定し, 観測変数間の関係を説明するモデル である. 探索因子分析のモデル式は,

$$
X=\Lambda \xi+\varepsilon
$$

と表現する。共分散行列は

$$
\Sigma_{x}=\Lambda \Phi \Lambda^{T}+\Delta
$$

となる.ここに， $\Lambda$ は因子負荷行列， $\Phi$ は因子間共分散 行列， $\Delta$ は独自性行列である. 探索的因子分析では，因 子負荷行列 $\Lambda$ と因子間共分散行列 $\Phi$ のすべての要素を 推定すべきパラメータとして扱う。ここで,

$$
\begin{gathered}
\Lambda^{*}=\Lambda\left(T^{-1}\right)^{T} \\
\Phi^{*}=T^{T} \Phi T
\end{gathered}
$$

なる変換を行うと,

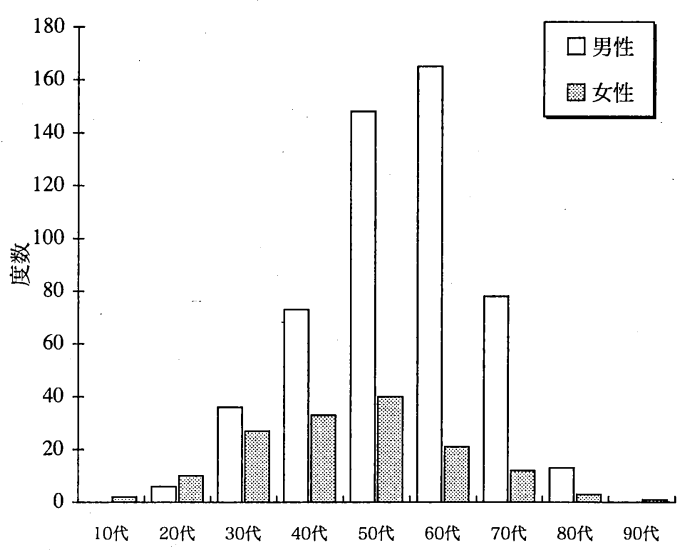

図 -2 回答者の年歯分布

$$
\begin{aligned}
\Sigma_{x} & =\Lambda \Phi \Lambda^{T}+\Delta=\Lambda T^{-1^{T}} T^{T} \Phi T T^{-1} \Lambda^{T}+\Delta \\
& =\Lambda^{*} \Phi^{*} \Lambda^{* T}+\Delta
\end{aligned}
$$

となり, $\Lambda$ とФは識別されないことになる ${ }^{15)}$.この変換 を因子の回転という.

このモデルを識別するためには $\Phi$ は単位行列, $\Lambda^{T} \Lambda$ は対角行列, $\Delta$ も対角行列という制約を入れて $\Lambda$ の要 素をすべて推定する。このとき，

$$
\Sigma_{x}=\Lambda \Lambda^{T}+\Delta
$$

と表現することができる共分散構造を持つものを直交モ デルという。 また, 共分散構造が

$$
\Sigma_{x}=\Lambda \Phi \Lambda^{T}+\Delta
$$

と表現することができるものを斜交モデルという.

\begin{tabular}{|c|c|c|c|c|c|c|c|c|c|c|c|}
\hline & & $\begin{array}{l}\text { 親しみ } \\
\text { やすい }\end{array}$ & $\begin{array}{c}\text { 技術的 } \\
\text { 制御不可能 }\end{array}$ & 不潔な & $\begin{array}{c}\text { リスク } \\
\text { 減少傾向 } \\
\end{array}$ & $\begin{array}{c}\text { 観察 } \\
\text { 不可能 }\end{array}$ & $\begin{array}{c}\text { 一般に } \\
\text { 未知 }\end{array}$ & $\begin{array}{l}\text { 恐ろし } \\
\text { くない }\end{array}$ & $\begin{array}{c}\text { 科学的に } \\
\text { 解明 }\end{array}$ & 単純な & $\begin{array}{c}\text { リスク } \\
\text { 軽減容易 } \\
\end{array}$ \\
\hline \multirow{2}{*}{ 琵琶湖 } & 平均 & 5.21 & 3.44 & 4.09 & 3.20 & 2.80 & 2.24 & 4.46 & 4.47 & 3.42 & 3.82 \\
\hline & 分散 & 1.44 & 1.45 & 1.27 & 1.13 & 1.21 & 1.48 & 1.41 & 1.26 & 1.14 & 1.28 \\
\hline \multirow{2}{*}{ 淀川 } & 平均 & 5.07 & 3.48 & 5.00 & 3.35 & 2.96 & 2.43 & 4.04 & 4.38 & 3.66 & 3.85 \\
\hline & 分散 & 1.59 & 1.47 & 1.32 & 1.26 & 1.26 & 1.41 & 1.36 & 1.26 & 1.21 & 1.33 \\
\hline \multirow{2}{*}{ 浄水場 } & 平均 & 3.81 & 2.55 & 3.12 & 3.48 & 2.65 & 3.09 & 4.38 & 5.03 & 3.83 & 4.30 \\
\hline & 分散 & 1.52 & 1.27 & 1.32 & 1.26 & 1.31 & 1.59 & 1.45 & 1.38 & 1.36 & 1.40 \\
\hline \multirow{2}{*}{ 高度浄水処理 } & 平均 & 3.73 & 2.77 & 2.66 & 3.62 & 2.89 & 4.28 & 4.51 & 4.86 & 3.50 & 4.22 \\
\hline & 分散 & 1.53 & 1.18 & 1.13 & 1.38 & 1.34 & 1.56 & 1.31 & 1.33 & 1.29 & 1.33 \\
\hline \multirow{2}{*}{ 水道管 } & 平均 & 4.45 & 2.84 & 3.89 & 3.48 & 3.52 & 2.79 & 4.15 & 4.78 & 4.37 & 4.14 \\
\hline & 分散 & 1.60 & 1.46 & 1.55 & 1.26 & 1.65 & 1.63 & 1.47 & 1.40 & 1.51 & 1.44 \\
\hline \multirow{2}{*}{ 原水水質 } & 平均 & 4.09 & 3.13 & 3.72 & 3.19 & 2.91 & 3.40 & 3.96 & 4.68 & 3.79 & 3.86 \\
\hline & 分散 & 1.59 & 1.46 & 1.54 & 1.24 & 1.34 & 1.69 & 1.45 & 1.40 & 1.28 & 1.39 \\
\hline \multirow{2}{*}{ 塩素処理 } & 平均 & 3.58 & 2.88 & 3.54 & 3.20 & 3.03 & 3.09 & 3.51 & 4.76 & 3.92 & 4.05 \\
\hline & 分散 & 1.51 & 1.23 & 1.29 & 1.20 & 1.33 & 1.56 & 1.46 & 1.40 & 1.35 & 1.32 \\
\hline \multirow{2}{*}{ トリハロメタン } & 平均 & 2.65 & 3.50 & 4.62 & 3.15 & 3.50 & 4.57 & 3.02 & 4.33 & 3.36 & 3.55 \\
\hline & 分散 & 1.54 & 1.43 & 1.37 & 1.24 & 1.47 & 1.76 & 1.43 & 1.51 & 1.31 & 1.34 \\
\hline
\end{tabular}

しかしながら，Tは式 (6) の条件の下で無数に存在す るために, 回転後の $\Lambda^{*}, \Phi^{*}$ も無数に存在する解の $1 つ$ にすぎない，直交回転ではバリマックス回転, 斜交回転 ではプロマックス回転など経験的に優れた $\Lambda^{*}, \Phi^{*}$ を与 える $T$ も提案されている.

確認的因子分析では,これらの欠点を克服するために,

表 -2 概念別の尺度得点平均とその分散 
$\Lambda, \Phi, \Delta$ に以下の 2 つの仮定を導入する. 1 つは, 母数行 列の要素の一部はあらかじめ先験的な值に固定でき，そ の值を推定する必要がないという仮定である.2つめは, 母数行列の要素の一部は先験的な情報から多の母数と一 定の関係を持たせながら推定することができるというも のである.

これにより，探索的因子分析では，全体的な因子負荷 の大小のパターンを利用して定量の分類を行うなど，定 性的な解釈しかできないが，確認的因子分析ではモデル が識別されているため, 観測変数を各因子の説明分散と 誤差分散に一意に分解することが可能であり, 因子から の影響力を定量的に解釈することができる.

\section{(2) 分析手法}

因子負荷量の推定方法は, 共通性の初期値として重相 関係数の平方, SMC を用い, 反復推定を行った主因子 法を用いた. 因子数の選択においては, 標本相関行列 $R$ の 1 より大きい固有值の数を因子数とするものとした.

そして, 推定された因子に対して, 因子間に相関がな いものと仮定する場合にはバリマックス回転を, 因子間 の相関の存在を認める場合にはプロマックス回転を行う ことで, 有意味な解釈が可能となる因子を抽出するもの とした. また, 因子得点の推定には回帰推定法を用いた。

データの分析には統計パッケージ SPSS Version 10.0.8を 用いた。

\section{4. 分析結果および考察}

\section{(1) 項目別因子分析モデル}

琵琶湖, 淀川, 浄水場, 高度浄水処理, 水道管, 水 道原水水質, 塩素処理, トリハロメタンという概念を, 表-3に示すように「水源」水道システム」「水道水質」 という3つの項目に分類した.ここでは, 分類したそれ ぞれの項目に対する観則変数は，その項目についての因 子からのみ影響を受けるものとし, それ以外の項目につ いての因子からの影響は受けないものとした.

因子負荷量が 0.4 未満および共通性が 0.35 未満の観測 変数を除外しながら繰り返し因子分析を行った. 因子分 析の手続きについては，まず，因子間の相関を考慮しな いバリマックス回転を行い, その因子構造を確認し, 抽 出する因子数を決定したのち, 因子間の相関を考慮した プロマックス回転を行った. 以下に分析結果について述 ベる.
a) 因子分析結果
琵琶湖，淀川に関する観測変数に因子分析を適用し， 3 因子を抽出した。この3因子に対してプロマックス回 転を行った因子構造行列を表-4に示す。これより，各

表 -3 分類項目とアンケート調査項目との対応

\begin{tabular}{cc}
\hline 分類項目 & アンケート調查項目 \\
\hline 水源 & 琵琶湖 \\
& 淀川 \\
\hline \multirow{2}{*}{ 水道システム } & 浄水場 \\
& 高度浄水処理 \\
& 水道管 \\
\hline \multirow{2}{*}{ 水道水質 } & 水道原水水質 \\
& 塩素処理 \\
& トリハロメタン \\
\hline
\end{tabular}

表 -4 プロマックス回転後の水源に関する因子構造行列

\begin{tabular}{l|c|ccc}
\hline & \multicolumn{1}{c}{ 第 1 因子 } & 第 2 因子 & 第 3 因子 & 共通性 \\
\hline A- 単純な & 0649 & -0.165 & -0.006 & 0.443 \\
B- 単純な & 0.661 & -0.223 & -0.121 & 0.447 \\
B- リスク㹩減容易 & 0663 & -0.464 & -0.111 & 0.475 \\
A- リスク柽減容易 & 0.602 & -0.435 & -0.021 & 0.401 \\
A- 技術的制御不可能 & -0278 & 0734 & 0.074 & 0.544 \\
B- 技術的制御不可能 & -0298 & 0.668 & 0.170 & 0451 \\
B-一般に未知 & -0100 & 0150 & 0.850 & 0.723 \\
A-一般に未知 & -0.051 & 0.096 & 0.623 & 0.389 \\
\hline 固有値 & 2.61 & 1.53 & 1.22 & \\
寄与率 & 2588 & 1365 & 8.89 & 48.41 \\
\hline 因子間相関行列 & \multicolumn{3}{|c}{} \\
第 1 因子 & 1.000 & -0.447 & -0.101 & \\
第 2 因子 & -0447 & 1.000 & 0.160 & \\
第 3 因子 & -0101 & 0.160 & 1.000 & \\
\hline
\end{tabular}

A：琵琶湖 B：淀川

観測変数の因子負荷量は，1つの因子についてのみ，そ の絶刘值が大きくなっていることから，その因子構造が 単純構造となっていることがわかる.

第 1 因子は，単純な，リスク軽減容易という尺度が高 く負荷していたことから，「安心」因子を解釈すること ができた，第 2 因子は，技術的制御不可能に対する因子 負荷量が高くなっていたことから，「潜在的リスク」因 子と解釈することができた．第 3 因子は，一般に未知 という尺度の負荷量が大きいことから，「未知性」因子 と解釈できた。このときの第 3 因子までの累積寄与率は 48.4\%である.

表 -5 にプロマックス回転後の水道システムに関する 因子構造行列を示す。ここでは，4因子が抽出され，こ のときの累積寄与率は $53.8 \%$ である. 各観測変数の因子 負荷量の絶対値から, 単純構造になっているといえる.

第 1 因子は，「高度浄水処理 - 観察不可能」「浄水場 観察不可能」「高度净水処理 - 技術的制御不可能」の因 子負荷量が高くなっていたことから,「未知性」因子と 解釈することができた．第 2 因子は, 恐ろしくないと いう尺度の負荷が高かったことから,「安心」因子と解 釈することができた。第 3 因子は，「高度浄水処理 - リ スク軽減容易」「浄水場 - リスク軽減容易」の因子負荷 量が大きく,「低リスク」因子と解釈した. 第 4 因子は, 水道管に関するリスク軽減容易, 科学的に解明という尺 
度の因子負荷量が高かったことから,「末端給水装置に 対する信頼」と解釈することができた。

水道水質に関する観測変数に因子分析を適用し, 2 因 子を抽出した. 表-6にプロマックス回転後の因子構造 行列を示す. 各観測変数の因子負荷量から, 因子構造が 単純構造になっていることがわかる。

第 1 因子は, 観察不可能という尺度が高く負荷して いたことから，「未知性」因子と解釈することができた。 第 2 因子は，「トリハロメタン - リスク減少傾向」「トリ ハロメタン - 恐ろしくない」の因子負荷量が高くなって いたことから,「トリハロメタンに対する安心」因子と 解釈することができた。 このとき，累積寄与率は $52.1 \%$ である.

b) 因子間相関の検討

水源に関する因子分析モデルでは, 表-4に示した因 子間相関行列より, 第 1 因子と第 2 因子の相関関係か強 い相関を示している. したがって, 水源について第 1 因 子である「安心」が大きくなるほど，第 2 因子の「潜在 的リスク」は小さくなるといえる。このことから,「安心」 「潜在的リスク」は，「安心感」という潜在的因子を表し ているものと考えられる. したがって，水源に対する因 子モデルは,「安心感」末知性」という潜在的因子によっ て構成されると推定できる。

水道システムに関する因子分析モデルでは，表 $-5 に$ 示した因子間相関行列より，第 2 因子，第 3 因子，第 4 因子は相互に強い相関を示している. また, これらの因 子の解釈結果より,「安心」低リスク」「末端給水装置 に対する信頼」因子は, 水道システムに対する「安心感」 という潜在的因子を表しているものと考えられる。この ことから, 水道システムに対する因子モデルは, 「未知性」 「安心感」という潜在的因子によって構成されていると 推定されよう。

表-6に示した水道水質に関する因子間相関行列より, 第 1 因子と第 2 因子との間には明確な相関関係があると はいえず，水道水質に対する認知を構成する潜在的因子 として，「未知性」因子と「安心感」因子の 2 因子をあ げることができる.

以上のことから, 水源, 水道システム, 水道水質に対 する認知を構成する潜在的因子として，「安心感」「未知 性」の潜在的因子が抽出され，水道水の認知においては 「安心感」因子,「未知性」因子が安定して抽出されるこ とがわかった，このことから，水道水に対するリスク認 知構造が，主として「安心感」因子，「未知性」因子の 2つの潜在的因子によって構成されているといえる。

次に, 潜在的因子間の関係について検討した。

各分類項目において抽出された因子について，プロ マックス回転後の因子得点を推定し，それらの相関分析 を行った. 表-7 に推定した因子得点の相関行列を示す.
表 -5 プロマックス回転後の水道システムに関する 因子構造行列

\begin{tabular}{|c|c|c|c|c|c|}
\hline & 第 1 因子 & 第 2 因子 & 第 3 因子 & 第 4 因子 & 共通性 \\
\hline B- 観祭不可能 & 0.787 & -0236 & -0.250 & -0.213 & 0635 \\
\hline A- 観察不可能 & 0.684 & -0.201 & -0.208 & -0.294 & 0.498 \\
\hline B- 技術的制御不可能 & 0.645 & -0.311 & -0.294 & -0.181 & 0.423 \\
\hline B- 不潔な & 0.647 & -0.436 & -0269 & -0198 & 0.457 \\
\hline B- 科学的に解明 & -0.565 & 0.567 & 0.465 & 0.419 & 0.471 \\
\hline B- 恐ろしくない & -0.361 & 0.748 & 0.448 & 0.276 & 0.586 \\
\hline A- 恐ろしくない & -0.261 & 0.712 & 0.311 & 0.350 & 0.512 \\
\hline C- 恐ろしくない & -0.192 & 0.608 & 0217 & 0.522 & 0.473 \\
\hline B- リスク怪減容易 & -0305 & 0.409 & 0.910 & 0.373 & 0833 \\
\hline A-リスク軽滅容易 & -0.342 & 0.414 & 0.678 & 0451 & 0.494 \\
\hline C- リスク怪減容易 & -0205 & 0.324 & 0.403 & 0751 & 0.584 \\
\hline C- 科学的に解明 & -0.397 & 0455 & 0.336 & 0.671 & 0.491 \\
\hline 固有値 & 4.32 & 1.72 & 1.14 & 1.01 & \\
\hline 寄与率 & 32.13 & 10.54 & 6.16 & 4.97 & 53.80 \\
\hline \multicolumn{6}{|l|}{ 因子間相関行列 } \\
\hline 第 1 因子 & 1.000 & -0.442 & -0394 & -0.342 & \\
\hline 第 2 因子 & -0.442 & 1000 & 0.484 & 0.483 & \\
\hline 第 3 因子 & -0.394 & 0484 & 1.000 & 0428 & \\
\hline 第 4 因子 & -0.342 & 0.483 & 0.428 & 1.000 & \\
\hline
\end{tabular}

$\mathrm{A}$ ：浄水場 $\mathrm{B}$ : 高度浄水処理 $\mathrm{C}$ ：水道管

表 -6 プロマックス回転後の水道水質に関する 因子構造行列

\begin{tabular}{|c|c|c|c|}
\hline & 第 1 因子 & 第 2 因子 & 共通性 \\
\hline 塩素処理 - 観察不可能 & 0.863 & 0.030 & 0.747 \\
\hline 原水水質 - 観察不可能 & 0.652 & 0.069 & 0.425 \\
\hline トリハロメタン - 観察不可能 & 0.589 & 0.102 & 0.350 \\
\hline トリハロメタン - リスク隇少傾向 & 0.101 & 0.780 & 0.610 \\
\hline トリハロメタン - 恐ろしくない & 0.041 & 0.686 & 0.471 \\
\hline 固有值 & 201 & 1.50 & \\
\hline 寄与率 & 31.04 & 21.01 & 52.05 \\
\hline \multicolumn{4}{|l|}{ 因子間相関行列 } \\
\hline 第 1 因子 & 1.000 & 0.087 & \\
\hline 第 2 因子 & 0.087 & 1.000 & \\
\hline
\end{tabular}

潜在変数である因子得点から観測変数への影響の大 きさは, 共通性によって示される。 したがって, 因子構 造行列より, 潜在変数から観測変数への影響指標は 0.350 〜 0.833 であるから, 潜在変数は観測変数によりかなり 適切に測定されているといえる.

「水源に対する安心」と「水道システムに対する安心」 「水道システムに対する低りスク」「末端給水装置に対す る信頼」との相関係数は 0.35 前後である. このことから, 水源に対する安心が大きい場合, 水道システムに対する 安心，水道システムに対する低リスク，末端給水装置に 対する信頼という水道システムに対する「安心感」因子 も大きいといえよう。

「水道システムに対する未知性」水道システムに対す る信頼」水道水質に対する未知性」は互いに強い相関 を示している，そこで，「水道システムに対する未知性」 と「水道水質に対する未知性」との因果関係に着目する.

平常時においては, 水道水質か水源から水道システム を経て給水された水道水の水質であることから, 「水道 
表-7 プロマックス回転による因子得点の相関行列

\begin{tabular}{|c|c|c|c|c|c|c|c|c|c|c|}
\hline 概念 & & $\begin{array}{l}\text { 水源 } \\
\text { 安心 }\end{array}$ & $\begin{array}{c}\text { 水源 } \\
\text { 潜在的リスク }\end{array}$ & $\begin{array}{l}\text { 水源 } \\
\text { 未知性 }\end{array}$ & $\begin{array}{c}\text { 水道システム } \\
\text { 未知性 }\end{array}$ & $\begin{array}{c}\text { 水道システム } \\
\text { 安心 } \\
\end{array}$ & $\begin{array}{c}\text { 水道システム } \\
\text { 低リスク } \\
\end{array}$ & $\begin{array}{c}\text { 水道システム } \\
\text { 信頼 } \\
\end{array}$ & $\begin{array}{c}\text { 水道水質 } \\
\text { 未知性 }\end{array}$ & $\begin{array}{c}\text { 水道水質 } \\
\text { 安心 }\end{array}$ \\
\hline \multirow{3}{*}{ 水源 } & 安心 & 1.000 & & & & & & & & \\
\hline & 潜在的リスク & $-0.556\left(^{*}\right)$ & 1.000 & & & & & & & \\
\hline & 未知性 & $-0.129(*)$ & $0.205\left(^{*}\right)$ & 1.000 & & & & & & \\
\hline \multirow{4}{*}{$\begin{array}{c}\text { 水道 } \\
\text { システム }\end{array}$} & 未知性 & $-0.156(*)$ & $0.254\left(^{*}\right)$ & $0.245\left(^{*}\right)$ & 1.000 & & & & & \\
\hline & 安心 & $0.322\left(^{*}\right)$ & $-0.242(*)$ & $-0.217\left(^{*}\right)$ & $-0.519(*)$ & 1.000 & & & & \\
\hline & 低リスク & $0.363\left(^{*}\right)$ & $-0.281(*)$ & $-0.152(*)$ & $-0.448\left(^{*}\right)$ & $0.566(*)$ & 1.000 & & & \\
\hline & 信頼 & $0.340\left(^{*}\right)$ & $-0.257(*)$ & $-0.207(*)$ & $-0.426\left({ }^{*}\right)$ & $0.605(*)$ & $0530\left(^{*}\right)$ & 1.000 & & \\
\hline \multirow{2}{*}{ 水道水質 } & 未知性 & -0.073 & $0.172(*)$ & $0.174(*)$ & $0.597(*)$ & $-0.198(*)$ & $-0.206\left(^{*}\right)$ & $-0.311\left({ }^{*}\right)$ & 1.000 & \\
\hline & 安心 & $0.242\left(^{*}\right)$ & $-0168\left(^{*}\right)$ & 0.030 & 0.070 & $0.128(*)$ & $0.159(*)$ & $0.129(*)$ & $0.106(*)$ & 1.000 \\
\hline
\end{tabular}

(*) $5 \%$ 水準で有意

システムに対する未知性」が「水道水質に対する未知性」 を規定しているものと考えられる。このとき，「水道シ ステムに対する未知性」が「水道システムに対する信頼」 と「水道水質に対する未知性」との 2 つの潜在因子を規 定することから，「水道システムに対する信頼」と「水 道水質に対する未知性」とが共変関係にあると推察でき よう。

一方，臭気問題など水道水質か湾化するような非常時 においては, 需要者はまず水道水質を認知することから, 「水道水質に対する未知性」が「水道システムに対する 未知性」を規定すると考えることができよう.そして, 「水 道システムに対する未知性」が大きくなると「水道シス テムに対する信頼」が小さくなることから，「水道水質 に対する未知性」が，間接的に「水道システムに対する 信頼」を規定してるものと推定することができる.

\section{(2) 構成概念別因子分析モデル}

項目別因子分析モデルでは，水道水に対するアンケー 卜調査項目を「水源」水道システム」「水道水質」とい う分類項目で分類したのち，探索的因子分析を行った。 その結果,それぞれの分類項目において,「安心感」と「未 知性」という2因子が抽出された。 しかしながら，各項 目に関する因子分析モデルで，同義の因子が抽出されて いる. また，因子分析モデルの変量モデルにおいては, 因子得点を一意に定めることができない ${ }^{13)}$ という因子得 点の不定性より, 潜在的因子間の構造が一意でなく, ま た，潜在的因子間の構造が単純構造であるとはいいがた い.

従来のリスク認知に関する研究では,「恐ろしさ」と「未 知性」の 2 因子が, 安定して抽出されている ${ }^{11,4.161 .17)}$. そ こで，アンケート調査における 80 の観測変数を「水源」 「水道システム」「水道水質」という 3 つ項目に分類し たのち，さらに，尺度について表-8に示すような3つ の潜在的構成概念を設け, 計 9 つに分類した。ここでは, このように分類されたものを構成概念として扱うものと した。「安心感」という潜在的構成概念に対する観測変
表 -8 潜在的構成概念による尺度の分類

\begin{tabular}{cc}
\hline 潜在的構成概念 & 尺度 \\
\hline 情報量 & 親しみやすい \\
& 一般に知られている \\
& 単純な \\
\hline & 技術的に制御不可能 \\
不潔な \\
安心感 \\
& リスクが隇少傾向 \\
& 恐ろしくない \\
& リスクの軽滅が容易 \\
\hline & 観察不可能 \\
未知性 & 一般に知られている \\
& 科学的に解明されている \\
& 単純な \\
\hline
\end{tabular}

数として，技術的に制御不可能，リスクが減少傾向，恐 ろしくない, .リスクの軽減が容易，という尺度を取り扱 うものとした。水道水に対する需要者のリスク認知に着 目していることから, 安心感が大きければ清浄なものと とらえているものと考え，不潔なという尺度についても 「安心感」の観測変数として扱うものとした．また，「未 知性」という潜在的構成概念に対する観測変数には，観 察不可能，一般に知られている，科学的に解明されてい る，単純な，という尺度をとりあげることとした。

また，「安心感」「未知性」という潜在的構成概念に加 えて「情報量」という潜在的構成概念を取り扱うものと した，この水源，水道システム，水道水質に対する情報 量は，需要者がそれらに関する情報をどの程度享受して いるのかを表すものである. McCombs と Shaw ${ }^{18)}$ は，リ スクコミュニケーションにおけるメディアの議題設定効 果について検討を行っている，そこでは，メディアが 一定期間, 比較的少数の争点や主題を強調してとりあげ ることにより，一般の人々はこれらの争点や主題を他の ものより目立つもの，あるいは重要なものとして認知す るようになるとしている. Mazar ${ }^{19)}$ は，科学論争につい てのメディアの報道量と人々の意見との間の関係を調査 し，両者の間に関係があるとしている，つまり，人々が 高度浄水処理に関する情報について多く得ると, 高度浄 水処理を重要なものと認知し，それが一般に知られてい 


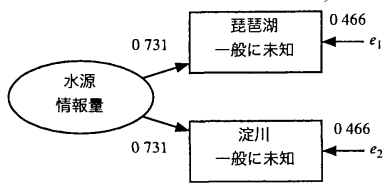

図 -3 水源に対する情報量の因子分析モデル，

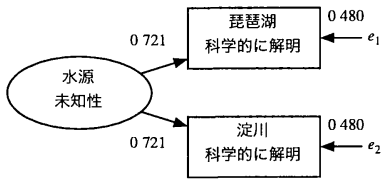

図 -4 水源に対する未知性の因子分析モデル

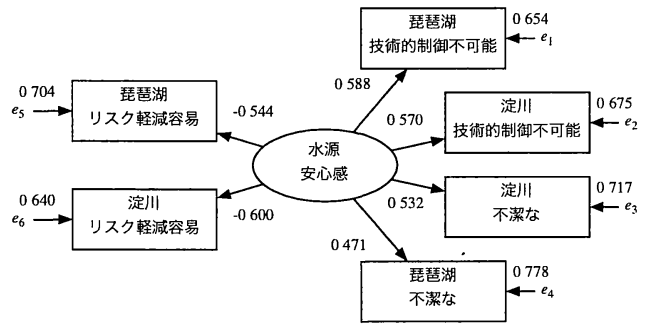

図 -5 水源に対する安心感の因子分析モデル

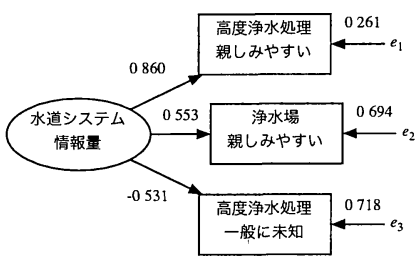

図 -6 水道システムに対する情報量の因子分析モデル

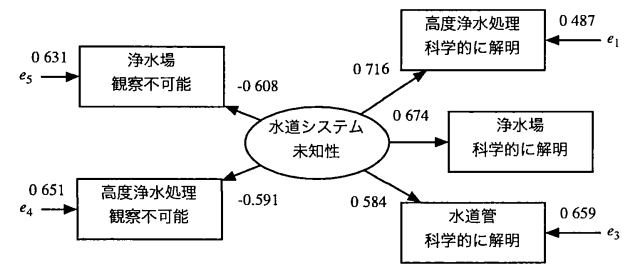

図 -7 水道システムに対する未知性の因子分析モデル

るものととらえるようになると考えられる. したがって, 「情報量」という潜在的構成概念に対する観測変数とし て, 一般に知られている, 親しみやすい, 単純なという 尺度をとりあげることとした。

そして, これらの構成概念は，その構成概念の観測変 数にだけ影響を与え，その他の観測変数に対しては影響 力を持たないものとし，それぞれの構成概念について探 索的因子分析を行った。

ここでは，因子負荷量が 0.4 未満および共通性が 0.35 未満の観測変数を除外しながら繰り返し因子分析を行つ た。また，個々の観測変数ができるだけ少数，できれば 1 個の因子からの影響を受け, 残りの因子からの影響指 標が 0 に近づくような単純構造を持つ解を求めるため,

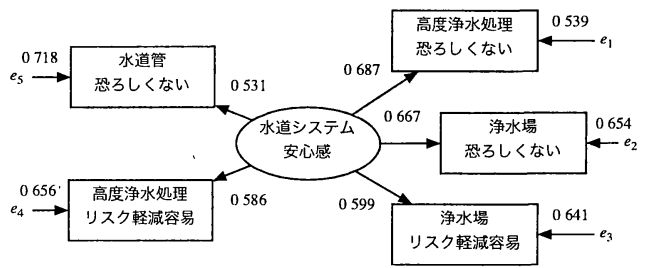

図-8 水道システムに対する安心感の因子分析モデル

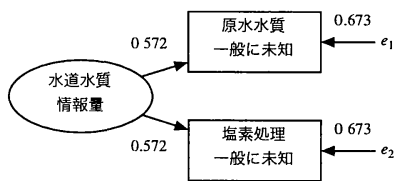

図 -9 水道水質に対する情報量の因子分析モデル

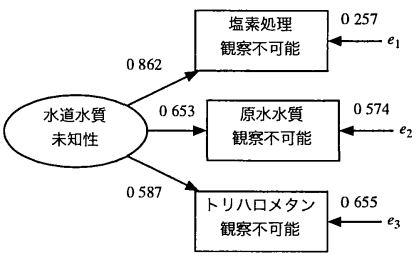

図-10 水道水質に対する未知性の因子分析モデル

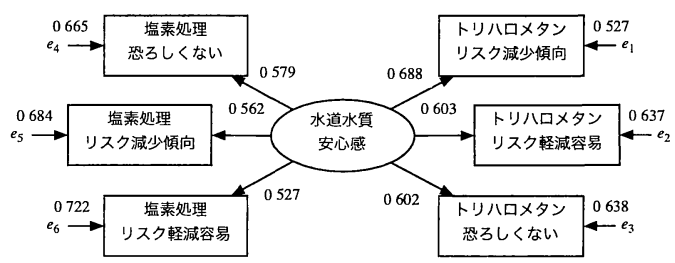

図-11 水道水質に対する安心感の因子分析モデル

表 -9 構成概念別因子分析モデルの寄与率と共通性

\begin{tabular}{llc}
\hline \multicolumn{1}{c}{ 構成概念 } & 寄与率 & 共通性 \\
\hline 水源に関する情報量 & $53.4 \%$ & 0.534 \\
水源に対する未知性 & $52.0 \%$ & 0.520 \\
水源に対する安心感 & $30.5 \%$ & $0.360 \sim 0.222$ \\
水道システムに関する情報量 & $44.2 \%$ & $0.739 \sim 0.282$ \\
水道システムに対する未知性 & $40.5 \%$ & $0.513 \sim 0.341$ \\
水道システムに対する安心感 & $38.0 \%$ & $0.471 \sim 0.282$ \\
水道水質に関する情報量 & $32.7 \%$ & 0327 \\
水道水質に対する未未知性 & $50.5 \%$ & $0.743 \sim 0.345$ \\
水道水質に対する安心感 & $35.5 \%$ & $0.73 \sim 0.278$ \\
\hline
\end{tabular}

1つの構成概念につき 1 つの因子を抽出するものとした。 それぞれの構成概念に分類された観測変数に対して因子 分析を適用し，その因子構造行列によるパス図を図 -3 ～図-11 に示す. また，表 -9 に構成概念別の因子分析 モデルの寄与率ならびに共通性の值を示す。これより, それぞれの構成概念において抽出された因子は，それぞ れの観測変数によって測定されており, 観測変数によっ て観測される構成概念であるといえよう。 
表 -10 構成概念に対する因子得点の相関行列

\begin{tabular}{|c|c|c|c|c|c|c|c|c|c|c|}
\hline 分類項目 & 構成概念 & $\begin{array}{c}\text { 水源 } \\
\text { 情報量 } \\
\end{array}$ & $\begin{array}{c}\text { 水源 } \\
\text { 未知性 }\end{array}$ & $\begin{array}{c}\text { 水源 } \\
\text { 安心感 }\end{array}$ & \begin{tabular}{|c} 
水道システム \\
情報量 \\
\end{tabular} & $\begin{array}{c}\text { 水道システム } \\
\text { 未知性 }\end{array}$ & \begin{tabular}{c|} 
水道システム \\
安心感
\end{tabular} & $\begin{array}{c}\text { 水道水質 } \\
\text { 情報量 } \\
\end{array}$ & $\begin{array}{c}\text { 水道水質 } \\
\text { 未知性 }\end{array}$ & $\begin{array}{c}\text { 水道水質 } \\
\text { 安心感 }\end{array}$ \\
\hline \multirow{3}{*}{ 水源 } & 情報量 & 1.000 & & & & & & & & \\
\hline & 未知性 & $-0.151\left(^{*}\right)$ & 1000 & & & & & & & \\
\hline & 安心感 & $0.136(*)$ & $-0.355\left(^{*}\right)$ & 1.000 & & & & & & \\
\hline \multirow{3}{*}{$\begin{array}{c}\text { 水道 } \\
\text { システム }\end{array}$} & 情報量 & 0.032 & $-0.184\left(^{*}\right)$ & $0.316\left(^{*}\right)$ & 1.000 & & & & & \\
\hline & 未知性 & $-0.218\left(^{*}\right)$ & $0.431\left(^{*}\right)$ & $-0.234\left(^{*}\right)$ & $-0.300(*)$ & 1.000 & & & & \\
\hline & 安心感 & $0.177\left(^{*}\right)$ & $-0.316\left(^{*}\right)$ & $0.368\left(^{*}\right)$ & $0.286(*)$ & $-0.539\left({ }^{*}\right)$ & 1.000 & & & \\
\hline \multirow{3}{*}{ 水道水質 } & 情報量 & $0.300(*)$ & $-0.128\left(^{*}\right)$ & $0.107(*)$ & $0.243(*)$ & $-0.324\left(^{*}\right)$ & $0.180(*)$ & 1.000 & & \\
\hline & 未知性 & $-0.157\left(^{*}\right)$ & $0.198\left(^{*}\right)$ & $-0.164\left(^{*}\right)$ & $-0.201\left(^{*}\right)$ & $0.534\left(^{*}\right)$ & $-0.195(*)$ & $-0.375\left(^{*}\right)$ & 1.000 & \\
\hline & 安心感 & 0.014 & $-0.182\left(^{*}\right)$ & $0.363\left({ }^{*}\right)$ & $0.234\left(^{*}\right)$ & $-0.142\left(^{*}\right)$ & $0.389(*)$ & -0.053 & -0.028 & 1.000 \\
\hline
\end{tabular}

(*) $5 \%$ 水準で有意

図-3に示した水源に対する情報量の因子分析モデル においては，一般に未知という尺度の因子負荷量が正の 值であることから，この抽出された因子の正の方向が一 般に未知と関連力強く，この因子による因子得点が大き くなるほど一般に未知という尺度に対する観測値が大き くなるといえる，一方，構成概念である「水源に対する 情報量」が大きくなるとき，一般に未知という尺度に対 する観則值は小さくなると考えられる，したがって，水 源に対する情報量」が大きくなるほど，抽出された因子 により推定される因子得点は小さくなるといえる.

また，水源に対する未知性，水源に対する安心感，水 道システムに対する未知性，水道水質に対する情報量の 因子分析モデルについても，水源に対する情報量と同様 に，構成概念が大きくなるほど，推定される因子得点は 小さくなるといえる.

以上より，アンケート調査結果における観測変数を 9 つの構成概念に分類することで, 構成概念と観測変数と の関係を因子モデルとして表現することができた。

次に，これら構成概念間の関係について検討した。

それぞれの構成概念において抽出された因子につい て, その因子得点を推定し, それらの相関分析を行った. これらの構成概念には，構成概念が大きくなるほど，抽 出された因子の因子得点が小さくなる構成概念が存在す る.

因子分析の変量モデルにおいては，すべての個体があ る特定の母集団からランダムに選ばれた，独立に同一の 分布に従う標本とみなされる ${ }^{133}$ ，つまり，ここでは，共 通因子，，は確率変数とみなされ，その期待值はゼ口と仮 定される。.また，その分散は 1 ，と仮定される。この ことから，推定された因子得点行列 $\xi に-1$ を乗じた行 列 $\xi^{\prime}$

$$
\xi^{\prime}=-\xi
$$

を用いることで, 因子の解釈を反転させることができる. つまり，構成概念が大きくなるほど，その因子得点 $\xi^{\prime} も$ 大きくなることとなる.

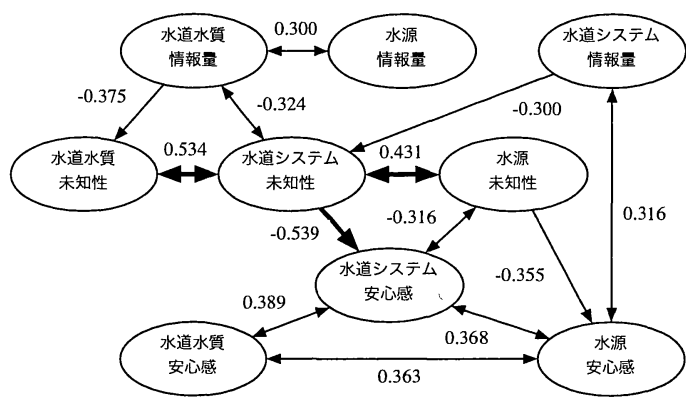

図-12，水道水のリスク認知に関する構成概念間構造

ここでは, 水源に対する情報量, 水源に対する安心感, 水源に対する未知性，水道システムに対する未知性，水 道水質に対する情報量，という5つの構成概念について は式(8)による変換を行った因子得点を用いた。

表-10に推定した構成概念の因子得点の相関行列を 示す．そして，この相関係数の絶対值が 0.3 以上となる 相関関係をとりあげ，構成概念間の関係をパス図として 表現したものを図-12に示す.

水源という分類項目においては，「水源に対する未知 性」と「水源に対する安心感」との相関係数は -0.355 と ある程度の相関が認められるが，「水源に関する情報量」 と「水源に対する未知性」「水源に対する安心感」との 相関関係は大きいとはいえない，したがって，水源に関 してよく知れば必ずしも水源に対する安心感が大きくな るというものではなく，水源に対する未知性が低減する ことで安心感が大きくなる，と推察することができる.

分類項目の水道システムに着目すると, 「水道システ ムに対する未知性」と「水道システムに対する安心感」 との相関係数が -0.539 と強い相関を示している。「水道 システムに関する情報量」と「水道システムに対する未 知性」ならびに「水道システムに対する安心感」との相 関関係も認められる。 また，潜在的構成概念である「情 報量」「未知性」「安心感」の関係の整合性より，「水道 システムに関する情報量」が「水道システムに対する未 知性」「水道システムに対する安心感」を規定するとい 
う方向を考えることができる，したがって，水道システ ムに対するリスク認知において, 情報量 $\rightarrow$ 未知性一安心 感という因果連鎖を推定することができる，つまり,「水 道システムに対する安心感」は，「水道システムに対す る情報量」から直接的に規定されるだけでなく,「水道 システムに対する未知性」により間接的に規定されてい る，ということである.

次に, 水道水質に着目すると, 「水道水質に関する情 報量」と「水道水質に対する未知性」との間にのみ有意 な相関関係か認められる。このことから，「水道水質に 関する情報量」が大きくなると，「水道水質に対する未 知性」が小さくなるが,「水道水質に対する安心感」は 「水道水質に関する情報量」あるいは「水道水質に対す る未知性」により直接的に規定されていないものと推定 することができる，つまり，水道水質に関してよく知る ことで必ずしも安心できるというものではない, という ことである. 竹村ら ${ }^{20)}$ は, 高度浄水導入により味・に おいに関して不満・不安に感じている人は 80\%〜90\% 減少したが, 安全性に関して不満・不安に感じている人 は 40\%〜 60\% 程度しか減少していないと報告している. 味・においは味覚・嗅覚による情報と考えられることか ら, これらに関する不満・不安に感じている人が減少し ていることは水道水質に関する情報を得ていたものと考 えることができよう，その一方で, 安全性に関して不満・ 不安に感じている人があまり減少していないことは, 水 道水質に関してよく知れば安心できるというものではな い, ということと合致するものと考えられる.

次に, 潜在的構成概念間の関係について述べる.

「情報量」と「未知性」については, 図-12に示した 構成概念間構造より,「水道システムに対する未知性」 は「情報量」により規定されているもの推定することが できる. つまり, 水源, 水道システム, 水道水質に関す る「情報量」が増大すると,「水道システムに対する未 知性」が減少する，といえる。

「水道水質に対する未知性」と「安心感」との間には 統計的に有意な相関関係が認められない，もしくは相関 関係が小さいことから,「水道水質に対する未知性」は「安 心感」に対して直接的な影響を与えていないと推定する ことができる. 図-12に示したパス図より「水道シス テムに対する未知性」と「水道水源に対する未知性」は, 「水道システムに対する安心感」水源に対する安心感」 に影響を与えているといえる. また,「水道システムに 対する未知性」と「情報量」との間にも相関関係が存在 していることから,「水道システムに対する未知性」は, 「情報量」によって規定される構成概念であり,さらに「安 心感」を規定している構成概念であるといえる。

「情報量」と「安心感」について述べる。「水道システ ムに関する情報量」と「水源に対する安心感」との間の
相関係数が 0.316 であることから,「水源に対する安心感」 は「水道システムに対する情報量」による影響を受けて いるものと考えられる。しかしながら，それ以外の「情 報量」と「安心感」との間には統計的に有意な相関関係 が存在しない, あるいは相関係数が小さくなっている.

因果の連鎖が存在した場合，連鎖の始めに位置する 変数と, 終わりに位置する変数との相関係数は小さくな $3^{21}$. 図-12より「情報量」と「未知性」「未知性」と「安 心感」との間には, 強い相関や複数のパスが認められた が,「情報量」と「安心感」との相関関係は小さいこと がわかる.このことから, 水道水のリスク認知において は,「情報量」により「未知性」が規定され,この「未知性」 によって「安心感」か規定されるという因果連鎖を推定 することができる. したがって, 水道水に関する情報量 が多くなれば安心できるというのではなく, 水道水に対 する未知性が低減することで安心することができる，と いえよう。

ここでは，水道水のリスク認知構造のモデル化を試 みたが, 因子分析モデルはあくまでも観測変数と潜在的 因子との関係を扱う測定方程式モデルであることから, 本研究は水道水のリスク認知構造を探るための探索型の リスク認知研究であると考えられる. したがって, 今回 得られた構成概念を明確化し, リスク認知構造を実証す るために, 測定方程式モデルだけではなく因果関係を扱 う構造方程式モデルを同時に扱うことが可能となるアン ケート調査の設計や分析方法, あるいは事例研究などの さらなる検討が必要であるといえる．また，本研究は， あくまでも現状における需要者の水道水に対するリスク 認知のありようを明らかにすることを目的としているこ とから, 情報提示による社会調査などの方法を用いて, 需要者の知識量, 情報量とリスク認知との関連について 追試実証を行う必要がある.ささらに, 需要者の飲用形態 や水道水の使用用途などを考慮していくことが必要であ るといえよう. 今後, 人々の水道水に対するリスク認知 構造モデルを用いて, 需要者の不安感を低減することが できるような情報公開技術のあり方を検討していくこと が必要であると考えられる。

\section{4. 結言}

本研究で得られた知見を以下に記す。

1. 確認的因子分析法を用いて, 水源, 水道システム, 水道水質に対する認知を構成する潜在的因子として, 「安心感「未知性」の因子か抽出され，水道水のリス ク認知おいては「安心感」因子,「未知性」因子が安 定して抽出されることがわかった.

2. 水源, 水道システム, 水道水質という分類項目に加 
えて，安心感，未知性，情報量という潜在的構成概 念を考慮に入れた確認的因子分析を行った。 その結 果得られた因子分析モデルを用いて推定した因子得 点より, 需要者の水道水に対するリスク認知におけ る構成概念間の構造モデルを構築することができた。

3. 需要者は, 水源に関してょく知れば必ずしも水源に 対する安心感が大きくなるというものではなく, 水 源に対する未知性が低減することで安心感が大きく なると推定することができた．また，水道水質に関 してょく知ることで必ずしも安心できるというもの ではない,といえた。

4. 水道水のリスク認知において,「情報量」により「未 知性」が規定され,この「未知性」によって「安心感」 が規定されるという因果連鎖を推定することができ， 水道水に関する情報量が多くなれば必ずしも安心で きるというのではなく，水道水に対する未知性が低 減することで安心することができる，といえた。

\section{参考文献}

1) Slovic, P.: Perception of risk, Science, Vol.236, pp.280-285, 1987.

2) Slovic, P., Fischhoff, B., and Lichtenstein, S.: Facts and fears: understanding perceived risk. In Schwing, R.R. \& Albers, Jr. W. A. (Eds.)., Social risk assessment - how safe enough? -, pp.181-216, 1980.

3) 岡本浩一: リスク心理学入門, サイエンス社, 1992.

4) Kleinhesselink, R. and Rosa, E. A.: Cognitive representation of risk perceptions: A comparison of Japan and the United States, Journal of Cross-cultual Psychology, Vol. 28, pp.11-28, 1991.

5) 伊藤禎彦, 平山修久: 需要者の水道水に対するリスク認 知地図に関する考察, 第 37 回日本水環境学会年会講演集, p.225, 2003.

6) Guttman, L. A.: Multiple group methods for common-factor analysis: their basis, computation, and interpretation, Psychometrika, Vol.17, pp.209-222, 1952.
7) Joreskog, K. G.: A general approach to confirmatory maximum likelihood factor analysis, Psychometrika, Vol.34, pp.183-202, 1969.

8) 黒船 2003 近畿版 : 株式会社データスケープ\&コミュニ ケーションズ.

9) 岩下豊彦：SD 法によるイメージの測定,川島書店, 1983.

10) 井上正明, 小林利宣：日本における SD 法による研究 分野とその形容詞対尺度構成の概観, 教育心理学研究, Vol.33, pp.253-260, 1985.

11) 住友恒, 村上仁士, 伊藤禎彦: 環境工学, 理工図書, 1998.

12) Owen, A. J., Colbourne, J. S., Clayton, C. R. I., and Fife-Schaw, C.: A mental model's approach to customer perception of drinking-water supply and quality, Water and Environmental Management, Vol.13, No.4, pp.241-244, 1999.

13）柳井晴夫, 繁枡算男, 前川眞一, 市川雅教 : 因子分析一 その理論と方法一, 朝倉書店, 1990 .

14）豊田秀樹：SASによる共分散構造分析, 東京大学出版会, 1992.

15) 芝祐順：因子分析法, 東京大学出版会, 1979.

16) Slovic, P.: Informing and educating the public about risk, Risk Analysis, Vol.6, pp.403-415, 1986.

17) Englander, T., Farago, K., Slovic P., and Fishhoff, B.: A comparative analysis of risk perception in Hungry and the United States, Social Behavior, Vol. 1, pp.55-56, 1986.

18) McCombs, M. and Shaw, D. L.: The agenda-setting function of mass media, Public Opinion Quarterly, Vol. 36, pp.176-187, 1972.

19) Mazur, A.: Media coverage and public opinion on scientific controversies, Journal of Communication, Vol. 31, pp.106-115, 1981.

20) 竹村仁志, 三浦浩之, 和田安彦 : 都市居住者の高度浄水 に対する評価に関する研究，環境システム研究，Vol.27， pp.277-283, 1999.

21) 安田三郎, 海野道郎 : 社会統計学, 丸善, 1997.

\title{
STRUCTURAL MODELING OF CONSTRUCTS CONCERNING RISK PERCEPTION OF WATER SUPPLY SYSTEM
}

\author{
Nagahisa HIRAYAMA, Sadahiko ITOH and Kousuke KAGAWA
}

\begin{abstract}
The process of risk communications is important for designing future water supply systems. The purpose of this study is to investigate the structure of customer's risk perception on water supply system. A queationnairing for the people in Osaka prefecture by a semantic differential method was carried out. A structural model of constructs concerning risk perception of water supply system was developed by confirmatory factor analysis. It was shown that the amount of information, unknown risk, and sense of security was linked by a causal structure. It was pointed out that sense of security does not always increase by knowing bettter on the quality of tap water.
\end{abstract}

